\title{
Iron Profile of Octopus Hubbsorum (Cephalopoda: Octopodidae) for Enrichment of the Mexican Diet
}

\author{
Palacios-Abrantes Juliano ${ }^{1}$, Melo-Ruiz Virginia ${ }^{1}$, Diaz-Garcia Rafael ${ }^{1}$, Gazga-Urioste César ${ }^{1}$ and Urbano Brian ${ }^{2}$ \\ 1. Departamento de Sistemas Biológicos, Universidad Autónoma Metropolitana Unidad Xochimilco. Calzada del hueso 1100, Col. \\ Villa Quietud, Delegación Coyoacán, C.P. 04960, D.F. México \\ 2. Laboratorio de Malacología, Instituto de Ciencias del mar y Limnología, Universidad Nacional Autónoma de México. Exterior s/n \\ Ciudad Universitaria, Coyoacán, 04510 Ciudad de D.F. México
}

\begin{abstract}
FAO (Food and Agriculture Organization of the United Nations) declared that 12\% of the world's population is undernourished while in Mexico the number is around 5\%. Minerals are essential for the daily diet; iron (Fe) is an important mineral on human welfare because it has a main role on the function of the immune and central nervous systems, among others. Most Mexicans fulfill their iron requirements from vegetables, which are poorly absorbed; nevertheless, in coastal populations, where seafood-rich in iron- is available, it is not consumed on a regular diet. The aim of this work was to analyze minerals, focusing on the iron content of Octopus hubbsorum B (Cephalopoda: Octopodidae), an animal of the Mexican Pacific coast. Three specimens were analyzed, two from the north and one from central Pacific Ocean. Data obtained for the central Pacific Octopus was $0.008 \%$ and data for the North Pacific were $0.008 \%$ and $0.011 \%$, repectively. In conclusion, the supply of iron for the Mexican diet provided by Octopus hubbsorum B is significant, therefore is recommended to consume more of this resource, to diminish iron deficiency, a world-wide problem, and to improve human health.
\end{abstract}

Key words: Iron, Mexico, octopus, nutrition, food security.

\section{Introduction}

Minerals are essential for humans and the lack of them is related to many degenerative diseases [1]. Iron $(\mathrm{Fe})$, is an important mineral that must be included on the diet since it is implicated in several functions [2], such as: chemical functions like electron transport, gene regulation and immune and central nervous systems regulation. It is also an essential element that acts as a key component for oxygen-carrying proteins; it is involved in cell growth and differentiation and it's a vital player in cellular metabolism $[2,3]$. For an adult, body's iron content must be $50 \mathrm{mg} / \mathrm{kg}$ [1] due to its high storage ratio, approximately 1 to $2 \mathrm{mg}$ are lost from the body per day $[1,4]$. With the exception of the losses caused by menstruation and pregnancy, the daily needs are considerably low for humans [5]. Iron

Corresponding author: Palacios Abrantes Juliano, master in science, research field: seafood. anemia is the most common nutritional deficiency worldwide [6], but it's not the only illness caused by the lack of this metal [2]. Maternal iron deficiency is the most common cause of newborn iron deficiency worldwide [7], affecting from $30 \%$ to $50 \%$ of the pregnancies around the world and if the poor intake occurs during the first six months of pregnancy, the increase of pre-labor activities, low birthweight and even the maternal neonatal's mortality tend to increase [8].

For humans, the absorption of iron included in food from animal sources has higher absorption rates than the one of edible vegetable plants [1]. However, most Mexicans fulfill their iron needs from vegetables (which have poor absorption rates) and coastal population include fish scarcely on their diet [9], which is insufficient to cover human requirements of heme iron. In addition, it has been mentioned that the consumption of fiber affects the absorption of iron, $12 \mathrm{~g}$ /day of bran 
on a meal decreases iron absorption by $51 \%$ to $74 \%$, which is important for Mexican population whose basic nutrition is rich in cereals $[9,10]$.

Cephalopods are one of the most important marine resources worldwide and Mexico is not the exception [11]. During 2010, 169,500 tons of sea food (no fish included) were produced, from which 23,167 tons were octopus, being the tenth place of Mexico's marine species fisheries and the fourth place of mollusk fisheries [12]. Due to its economical relevance Octopus maya on the Caribbean and Octopus vulgaris on the Mexican Gulf are the principal fishery stock $[11,13]$.

On the Pacific Ocean, fisheries focus mainly on $O$. hubbsorum, O. macrocopus and lastly O. bimaculatus. Octopus hubbsorum B, is an endemic Mexican cephalopod that can only be found in the Pacific Ocean, from the California Gulf (north) to Oaxaca's State sea shore (south).

The aim of this study is to investigate the iron content of three Octopus hubbsorum B organisms from different Mexican regions and use this information to improve people' health, nutrition, food security and ecological sustainability.

\section{Materials and Methods}

\subsection{Sample Collection}

The sample process was achieved during August 2013. Octopus hubbsorum B was obtained from fisherman of two different localization; Acapulco bay on Guerrero State ( $\left.16^{\circ} 51^{\prime} 0^{\prime \prime} \mathrm{S}, 99^{\circ} 55^{\prime} 0^{\prime \prime} \mathrm{W}\right)$ and Los Cabos San José on Baja California State $\left(16^{\circ} 51^{\prime}\right.$ $\left.0^{\prime \prime} \mathrm{S}, 99^{\circ} 55^{\prime} 0^{\prime \prime} \mathrm{W}\right)$, both located on the Pacific Ocean. Samples were identified taxonomically in situ [14] and introduced immediately on a plastic container at $-4{ }^{\circ} \mathrm{C}$ for land transportation to Mexico City.

\subsection{Experimental Set Up}

Tentacles were cut of the "manto", one tentacle of each animal was randomly selected and deposited on $70 \%$ alcohol for further molecular analysis and record identification, the rest were cut in $4 \mathrm{~cm}$ cubic parts and then used for determination of moisture content by the direct drying method. Octopus material was dried for $24 \mathrm{~h}$ in an air-oven set at $60^{\circ} \mathrm{C}$ until constant weight of the sample was obtained; product was ground and pass through a 60 mesh sieve to homogenize the sample. Ash amount was determined by the dry ashing method. Samples were incinerated on a cold muffle furnace at $650{ }^{\circ} \mathrm{C}$ for $2 \mathrm{~h}$ or until whitish/greyish ash was obtained. Organic matter was burned off and the remaining inorganic material was used for iron determination by dissolving ash in 100 $\mathrm{mL}$ of $1 \mathrm{~N}$ hydrochloric acid and quantification of iron was made by atomic absorption spectrophotometry. All samples were performed by triplicate.

\section{Results and Discussion}

\subsection{Results}

Octopus studied are widely distributed at the coastal zone of the Pacific Ocean (Fig. 1).

Octopus can be found all year long; however there is a closure period between August and October, so the main fishing season is between April and July (Table 1).

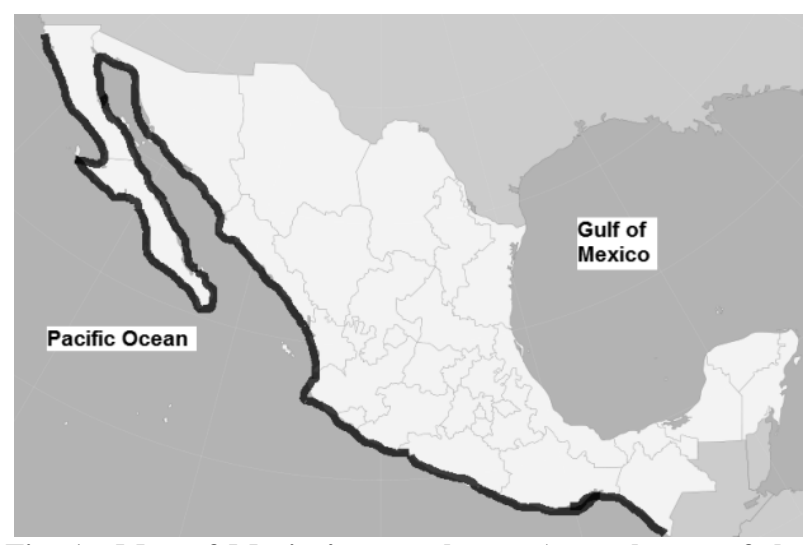

Fig. 1 Map of Mexico's coastal zone (coastal zone of the Pacific Ocean is highlighted).

Table 1 Octopus hubbsorum year abailability.

\begin{tabular}{|l|l|l|l|l|l|l|l|l|l|l|l|}
\hline J & F & M & A & M & J & J & A & S & O & N & D \\
\hline X & X & X & X & X & X & X & X & X & X & X & X \\
\hline
\end{tabular}
$\mathrm{X}=$ Months of the year in which the octopus resource can be produced.

$\mathbf{X}=$ Months of the year in which the production is considerably higher. 
The studied specie was Octopus hubbsorum B, an endemic Mexican cephalopod (Table 2).

Laboratory results showed that Acapulco's Octopus hubbsorum has a very high moisture rate, being this twice as much as the moisture found in the samples collected at Los Cabos (Table 3).

The total amount of inorganic matter determined by the dry ashing method was $7.78 \%$. Regarding iron content (Table 4), the analysis by atomic spectrophotometry showed that the amount of iron found in samples from Acapulco and from the south area of Los Cabos are pretty similar due to the similarities of these regions' environments. The environment at the north area of Los Cabos is slightly different, which explains the variation of iron content depending on the characteristics of the zone where octopuses live.

Iron deficiency anemia is still a major nutritional problem in vulnerable population worldwide because it can lead to negative changes in psychomotor and

Table 2 Taxonomic determination.

\begin{tabular}{ll}
\hline Taxonomic category & \\
\hline Kingdom & Animalia \\
Phylum & Mollusca \\
Class & Cephalopoda \\
Subclass & Coleoidea \\
Superorder & Octobranchia \\
Order & Octopoda \\
SubOrder & Incirrina \\
Family & Octopodidae \\
Genus & Octopus \\
Species & Octopus hubbsorum Berry, 1953 \\
\hline
\end{tabular}

Table 3 Moisture \% determination of Octopus hubbsorum B.

\begin{tabular}{llll}
\hline & Acapulco & Cabos a $^{*}$ & Cabos b $^{* *}$ \\
\hline Moisture & 50.57 & 20.57 & 24.19 \\
Dry sample & 49.43 & 79.43 & 75.81 \\
\hline
\end{tabular}

*South region; **North region.

Table 4 Iron content in Octopus hubbsorum Berry, 1953 (g/100g dry basis).

\begin{tabular}{llll}
\hline & Acapulco & Cabos a $^{*}$ & Cabos b $^{* *}$ \\
\hline Iron & 0.008 & 0.008 & 0.011 \\
\hline
\end{tabular}

*South region; **North region.
Table 5 Iron dietary requirements in humans. RDA (recommended daily allowance). Data from Food and Nutrition Board institute of Medicine, 2001.

\begin{tabular}{lll}
\hline Age & Gender & $\mathrm{mg} /$ day \\
\hline $50+$ years & Adult men & 6 \\
$50+$ years & Adult women & 8.1 \\
\hline
\end{tabular}

mental development, which may be irreversible due to the vital functions of this mineral on the body. The amount of iron in octopus samples represents a good source of this essential element that could be of great help to cover the requirements for human daily diet (Table 5). In this context, octopus consumption may be considered as an option for the improvement of human health, due to the important functions that iron plays within the body's metabolism and other important processes.

In addition to the aforementioned, octopus provide heme iron that is readily absorbed (about $30 \%$ ), in contrast to the non-heme iron found in vegetable sources whose absorption is pretty low (about $5 \%$ if it is consumed with vitamin C). However, the absorption is influenced by iron storage as ferritin, by the dietary content, and by iron bioavailability on the daily diet [15].

\section{Conclusions}

The iron provided by Octopus hubbsorum, B to human nutrition is vital, therefore is recommended to consume more of this resource to diminish iron deficiency, a world-wide problem, and to improve human health and well-being.

\section{References}

[1] Reilly, C. 2006. The Nutritional Trace Metals. Oxford: Blackwell Publishing. 35-70.

[2] Beard, J. 2006. "Iron." In Present Knowledge in Nutrition, 9th ed, edited by Bowman, B., \& Russell, R. Washington DC: International Life Sciences Institute, 430-44.

[3] Nemeth, E., and Ganz, T. 2006. "Regulation of Iron Metabolism by Hepcidin.” Annu. Rev. Nutr. 26: 323-42.

[4] Hunt, J. R., Zito, C. A., and Johnson, L. 2009. "Body Iron Excretion by Healthy Men and Women.” Am J Clin Nutr 89 (6): 1792-8. 
[5] Ray, Yip. 2003. Hierro. In Barbara Bowman \& Robert Russell Ed. Conocimientos Actuals Sobre Nutrición. Organización Panamericana de la Salud. Washington, DC. 340-59.

[6] Martínez-Salgado, H., Casanueva, E., Rivera-Dommarco, J., Viteri, J., and Bourgues-Rodríguez, H. 2008. "La Deficiencia de Hierro y la Anemia en Niños Mexicanos. Acciones Para Prevenirlas y Corregirlas.” Bol. Med. Hosp. Infant. Mex. 65: 86-99.

[7] WHO (World Helath Organization). 2008. "Micronutrient Deficiences." http://www.who.int/nutrition/topics/ida/en/.

[8] Khan, L., Wojdya, D., Say, I., Gulmezoglu, A. M., and Van Look P. F. 2006. "WHO Analysis of Causes of Maternal Death: A Systematic Review." Lancet. 367: 1066-74.

[9] Martínez, I., and Villezca, P. 2003. "La Alimentación en México: un Estudio a Partir de la Encuesta Nacional de Ingresos y Gastos de los Hogares.” Rev. Info, y Anal. 21: 26-37.

[10] Vieteri, F. E., and Torum, B. 1974. "Anemia and Physical Work Capacity." Clin Hematol. 3: 609-26.
[11] Alejo-Plata, C. R., Gómez-Márquez, J. L., Ramos, S., and Herrera-Galindo, J. E. 2009. "Reproducción, Dieta y Pesquería Del Pulpo Octopus (Octopus) Hubssorum (Mollusca:Cephalopoda) en la Costa de OAXACA." Revista Biología Tropical 57(1-2): 63-78.

[12] SAGARPA. 2004. Anuario Estadístico de Pesca. Secretaría de Agricultura, Ganadería, Desarrollo Rural, Pesca y Alimentación. México, D.F. 266.

[13] Arreguín-Sánchez, F., Solís-Ramírez, M., and Gonsales de la Rosa, M. 2000. "Population Dynamics and Stock Assessment of Octopus Maya (Cephalopoda: Octopodidae) Fishery in the Campeche Bank, Gulf of México." Rev. Biol. Trop. 48(2-3): 323-31.

[14] Roper, C. L., Sweeney, M. J., and Nauen, C. E. 1984. Species Catalog. Vol 3. Cephalopods of the World. An Annotated and Illustrated Catalogue of Species of Interest to Fisheries. FAO Fisheries Synopsis.

[15] FAO/WHO (Food and Agricultural Organization of the United Nations/World Health Organization). 2004. Vitamin and Mineral Requirements in Human Nutrition. Geneva, Switzerland. 